\title{
Measurement of late-night salivary cortisol with an automated immunoassay system
}

\author{
Michael Vogeser ${ }^{1, *}$, Jürgen Durner ${ }^{1}$, Ewald \\ Seliger $^{2}$ and Christoph Auernhammer ${ }^{3}$ \\ ${ }^{1}$ Institute of Clinical Chemistry, Hospital of the \\ University of Munich, Munich, Germany \\ ${ }^{2}$ Department of Obstetrics and Reproductive \\ Medicine, Hospital of the Martin Luther University, \\ Halle, Germany \\ ${ }^{3}$ Department of Internal Medicine 2, Hospital of the \\ University of Munich, Munich, Germany
}

\begin{abstract}
Background: Measurement of late-night salivary cortisol concentrations is increasingly used as a screening test in suspected Cushing's syndrome. Cortisol concentrations are typically extremely low in latenight samples and discordant assay-specific reference ranges have been reported. Therefore, the aim of our study was to assess the analytical performance of the first automated cortisol immunoassay specified for salivary measurements and to establish late-night sampling reference-range data for this test.

Methods: Salivary cortisol was measured using the Roche Cobas Cortisol assay (Roche Diagnostics). Five salivary pools in different concentration ranges were used to assess the inter-assay imprecision of this test in a two-centre evaluation protocol including two reagent lots. Linearity was tested by serial dilution. Salivary samples were obtained at 23:00 h from 100 apparently healthy volunteers using a commercially available salivary sampling device (Salivette, Sarstedt). A subset of 20 samples was used for method comparison with isotope dilution liquid chromatography-tandem mass spectrometry.
\end{abstract}

Results: Inter-assay coefficients of variation $(n=20)$ between $11.6 \%$ and $40.4 \%$ were found for mean cortisol concentrations between 12.9 and $2.6 \mathrm{nmol} / \mathrm{L}$, with an estimated functional sensitivity of approximately $5.0 \mathrm{nmol} / \mathrm{L}$. The test also gave linear results in the lowest concentration range between 1.0 and $8.3 \mathrm{nmol} / \mathrm{L}$. Mean late-night salivary cortisol of $5.0 \mathrm{nmol} / \mathrm{L}$ was found for healthy individuals; the absolute range was $1.4-16.7 \mathrm{nmol} / \mathrm{L}$, and the 95 th percentile was $8.9 \mathrm{nmol} / \mathrm{L}$. Substantially lower concentrations were found with isotope dilution LC-MS/MS compared to immunoassay results (mean concentrations 1.8 and $4.4 \mathrm{nmol} / \mathrm{L}$, respectively).

Conclusions: The automated assay investigated was found to offer acceptable analytical performance in the very low concentration range required for latenight salivary cortisol, despite a very short turnaround time. Using this assay, late-night salivary

*Corresponding author: Michael Vogeser, MD, Institute of Clinical Chemistry, Hospital of the University of Munich, Marchioninistraße 15, 81377 Munich, Germany Phone: + 49-89-70953221, Fax: + 49-89-70953240, E-mail: michael.vogeser@med.uni-muenchen.de cortisol concentrations below $8.9 \mathrm{nmol} / \mathrm{L}$ are typically found in healthy volunteers.

Clin Chem Lab Med 2006;44:1441-5.

Keywords: immunoassay; late-night salivary cortisol; liquid chromatography-tandem mass spectrometry (LC-MS/MS); reference range.

\section{Introduction}

Early signs of Cushing's syndrome are unspecific and may include weight gain, plethora, hypertension, glucose intolerance, depression, and irregularities of the menstrual cycle. Very similar presentations are common in insulin resistance syndrome and in polycystic ovary syndrome. It is not uncommon that Cushing's syndrome is diagnosed only in advanced disease states several years after the onset of symptoms, and so the disease is typically associated with substantial morbidity and mortality $(1,2)$. Mild forms of Cushing's syndrome, however, probably often remain undiagnosed in obese diabetic patients $(3,4)$. Therefore, reliable and convenient screening tests for Cushing's disease are of particular clinical importance. Standard laboratory investigations performed to rule out Cushing's syndrome include the dexamethasone suppression test, quantification of 24-h free urinary cortisol, and determination of midnight serum cortisol concentrations. Meanwhile, growing evidence suggests measurement of midnight or late-night salivary cortisol as a useful and convenient non-invasive method to be applied in the screening for Cushing's disease (5-7). In investigations carried out so far, laborious and typically radioactivity-based manual tests for salivary cortisol determination have been used (8-14). To date, only one automated cortisol immunoassay has specified saliva as a suitable sample material (Roche Cobas Cortisol) $(15,16)$. However, conclusive reference ranges have not been reported for this assay so far, and data published on the analytical performance of this test are limited. We therefore decided to validate this assay with a particular focus on reproducibility and agreement with an isotope dilution mass spectrometric method and to determine a reference range for late-night saliva samples.

\section{Materials and methods}

\section{Analytical method}

The Roche Cobas Cortisol ${ }^{\circledR}$ assay was used on an Elecsys 2010 immunoanalyser system (Roche Diagnostics, Mannheim, Germany). This is a competitive electrochemiluminescence immunoassay (ECLIA) using polyclonal sheep anticortisol antibodies. A $20-\mu \mathrm{L}$ sample is incubated with a cor- 
tisol-specific biotinylated antibody and a Tris(2,2'-bipyridyl) ruthenium(III)-labelled cortisol derivative. Subsequently, streptavidin-coated paramagnetic microparticles are added. Biotinylated antibodies bind to streptavidin on the microparticles. This complex is magnetically captured onto the surface of an electrode in the measurement cell. Application of a voltage to the electrode induces chemiluminescence of the ruthenium complex; the light signal is quantified by a photomultiplier. The total analysis time is $18 \mathrm{~min}$. The lower limit of quantitation of the method is $0.5 \mathrm{nmol} / \mathrm{L}$.

\section{Sample collection}

For collection of saliva, a commercially available sampling device was used (Salivette ${ }^{\circledR}$, Sarstedt, Nümbrecht, Germany). The system contains a polyester swab that is chewed by the patient for approximately $1 \mathrm{~min}$. Patients are instructed not to eat or drink for $1 \mathrm{~h}$ prior to sampling. The swab is then introduced into the system and capped. After centrifugation of the cartridge for $10 \mathrm{~min}$, typically $500 \mu \mathrm{L}$ of saliva is obtained in the lower portion of the sampling system. The system does not contain any preservative.

To prove that the sampling swab itself was free from compounds interacting with the immunometric cortisol determination, a swab was eluted with $500 \mu \mathrm{L}$ of system diluent (Elecsys Diluent Universal, Roche) and the eluate was analysed using the Cobas Cortisol test. A concentration below the lower limit of detection was reported by the analytical system.

\section{Assay validation}

To assess the linearity of the method, saliva was sampled from a healthy volunteer at 08:00 $\mathrm{h}$. This sample material was serially diluted 1:1 with the sample diluent of the cortisol assay (Elecsys Diluent Universal) in three steps. Cortisol was measured in duplicate in these four samples to compare the measured and expected results.

To investigate the imprecision of the method, saliva pools were prepared from specimens sampled from a healthy volunteer at different times. The pools were divided into aliquots and stored at $-20^{\circ} \mathrm{C}$ until analysis. The imprecision study was performed in two centres for five saliva pools. Analysis was thus performed in ten independent series at the University of Munich (centre 1), and at the University of Halle (centre 2). In the two centres, different reagent lots were used. In both centres the analyser systems were in routine use for a variety of analytes during the investigation period. Calibration and all maintenance procedures were performed as recommended by the manufacturer (re-calibration after 28 days). Quality control was performed according to the guidelines of the German Medical Association for quality assurance in medical laboratories using commercial quality control materials (Biorad Lyphocheck Immunoassay Controls, Biorad, Hercules, CA, USA; cortisol target concentrations 63.5 and $830 \mathrm{nmol} / \mathrm{L}$ ).

\section{Reference range investigation}

Saliva samples were obtained from 100 apparently healthy volunteers who gave informed consent to participation in this investigation. Only individuals without relevant acute or chronic health complaints were included. This was documented by the participants in a health questionnaire. Body weight and height were assessed, as was the use of drugs. Women taking hormonal contraceptive drugs were not excluded. The participants were instructed to take the samples at 23:00 h. The samples were frozen within $12 \mathrm{~h}$ after sampling and stored at $-20^{\circ} \mathrm{C}$ until analysis. Measurements were performed in two analytical series in the Institute of Clinical Chemistry of the University of Munich.

\section{Method comparison}

A total of 20 saliva samples were used for a method comparison study between the Cobas Cortisol assay and an isotope dilution liquid chromatography-tandem mass spectrometry (ID-LC-MS/MS) method (eight pooled samples, and 12 randomly selected samples from the reference range investigation). In the ID-LC-MS/MS method, tri-deuterated cortisol was used as the internal standard. After addition of the internal standard solution $(50 \mu \mathrm{L}$, concentration $5.520 \mathrm{nmol} / \mathrm{L})$ to $500-\mu \mathrm{L}$ samples and equilibration for $10 \mathrm{~min}$, solvent extraction with dichloromethane was performed for $20 \mathrm{~min}$ on a horizontal shaker. The organic phase was dried under a stream of nitrogen. The extract was taken up in $100 \mu \mathrm{L}$ of methanol/water (80:20 v/v). HPLC separation was performed on a $120 \times 4 \mathrm{~mm} \mathrm{C18} \mathrm{column} \mathrm{using} \mathrm{a} \mathrm{gradi-}$ ent programme. The injection volume was $50 \mu \mathrm{L}$. For detection, a Waters Micromass Quattro Ultima Pt MS/MS system was used in positive electrospray ionisation mode. For cortisol the mass transition $363 \rightarrow 121$ was recorded, and for trideuterated cortisol used as the internal standard, the mass transition $366 \rightarrow 121$ was monitored. The retention time for cortisol and the deuterated internal standard was $7.2 \mathrm{~min}$, and the total run time was $15 \mathrm{~min}$.

The study protocol was approved by the institutional Review Board.

\section{Results}

The cortisol assay was linear between 1.0 and $8.3 \mathrm{nmol} / \mathrm{L}$ (Table 1).

The results for the two-centre imprecision study including five saliva pools analysed in a total of 20 series using different reagent lots are given in Table 2 and Figure 1.

Of the 100 healthy volunteers included in the reference range investigation, 47 were female and 53 were male. The mean age was 38 years (range $14-59$ years) and the mean body mass index was $25.7 \mathrm{~kg} / \mathrm{m}^{2}$ (median 24.9 , range $18.8-38.6 \mathrm{~kg} / \mathrm{m}^{2}$ ). Fourteen participants took hormonal contraceptive drugs.

The mean cortisol concentration found in the samples taken at 23:00 $\mathrm{h}$ was $5.0 \mathrm{nmol} / \mathrm{L}$ (SD 2.4, median $4.7 \mathrm{nmol} / \mathrm{L})$. The absolute range was $1.4-16.7 \mathrm{nmol} / \mathrm{L}$ and the interquartile range was $3.2-6.2 \mathrm{nmol} / \mathrm{L}$. The 95 th percentile was $8.9 \mathrm{nmol} / \mathrm{L}$. The distribution of the concentrations found is shown in Figure 2.

Table 1 Investigation of dilution linearity with saliva as the sample material for the Roche Cobas cortisol assay.

\begin{tabular}{ll}
\hline $\begin{array}{l}\text { Observed } \\
\text { concentration, } \mathrm{nmol} / \mathrm{L}\end{array}$ & $\begin{array}{l}\text { Expected } \\
\text { concentration, } \mathrm{nmol} / \mathrm{L}\end{array}$ \\
\hline 8.3 (undiluted sample) & \\
4.1 & 4.1 \\
2.1 & 2.1 \\
1.0 & 1.0 \\
\hline
\end{tabular}

Conversion of units for cortisol: $[\mathrm{nmol} / \mathrm{L}] \times 0.0362 \rightarrow[\mu \mathrm{g} / \mathrm{dL}]$; $[\mu \mathrm{g} / \mathrm{dL}] \times 27.6 \rightarrow[\mathrm{nmol} / \mathrm{L}]$. 
Table 2 Results of the two-centre imprecision study of the Roche Cobas Cortisol assay with saliva as the sample material.

\begin{tabular}{|c|c|c|c|c|c|c|}
\hline & & Pool A & Pool B & Pool C & Pool D & Pool E \\
\hline \multirow{2}{*}{$\begin{array}{l}\text { Pooled data } \\
\text { bca }\end{array}$} & Mean, nmol/L & 12.9 & 11.2 & 6.3 & 3.2 & 2.6 \\
\hline & $\mathrm{CV}, \%$ & 11.6 & 11.9 & 16.4 & 27.1 & 40.4 \\
\hline \multirow[t]{2}{*}{ Centre 1} & Mean, nmol/L & 14.0 & 12.1 & 7.0 & 3.7 & 3.2 \\
\hline & $C V, \%$ & 6.3 & 9.7 & 12.8 & 22.1 & 34.3 \\
\hline \multirow[t]{2}{*}{ Centre 2} & Mean, nmol/L & 11.4 & 10.2 & 5.5 & 2.6 & 1.9 \\
\hline & $\mathrm{CV}, \%$ & 5.9 & 5.1 & 5.2 & 16.3 & 8.1 \\
\hline
\end{tabular}

Conversion of units for cortisol: $[\mathrm{nmol} / \mathrm{L}] \times 0.0362 \rightarrow[\mu \mathrm{g} / \mathrm{dL}] ;[\mu \mathrm{g} / \mathrm{dL}] \times 27.6 \rightarrow[\mathrm{nmol} / \mathrm{L}]$.

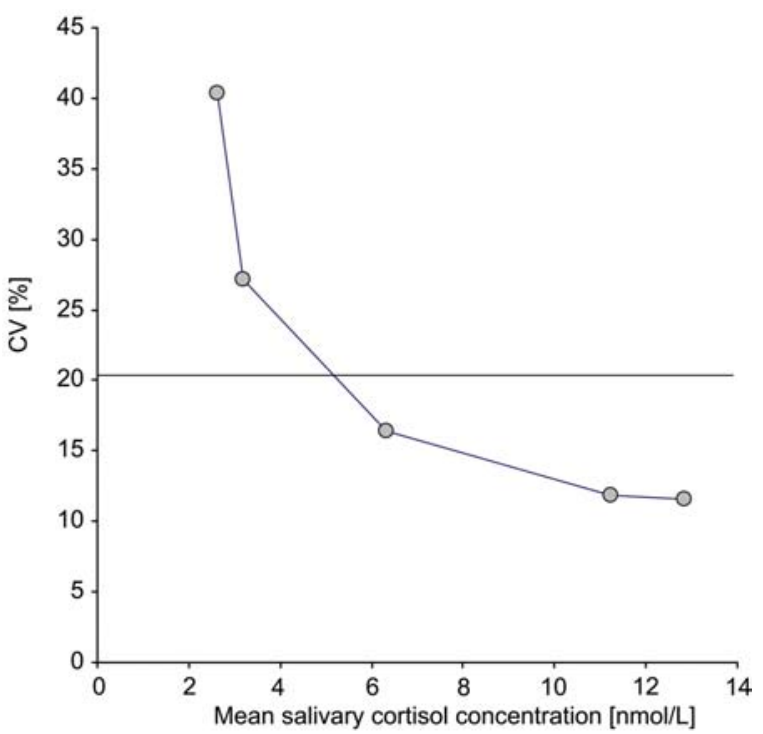

Figure 1 Precision profile of the Cobas Cortisol assay derived from data for the two-centre precision study.

Mean late-night salivary cortisol was $5.0 \mathrm{nmol} / \mathrm{L}$ in individuals with a body mass index below $30 \mathrm{~kg} / \mathrm{m}^{2}$, and $5.1 \mathrm{nmol} / \mathrm{L}$ in individuals with a body mass index above $30 \mathrm{~kg} / \mathrm{m}^{2}(\mathrm{n}=17)$; this difference was not significant (Wicoxon test). Concentrations found in women and men did not differ significantly. There was no significant difference in salivary cortisol concentrations for women taking hormonal contraceptive drugs compared to individuals not taking such drugs.

For the 20 saliva samples included for method comparison, substantially lower concentrations were found by ID-LC-MS/MS compared to the Cobas immunoassay (mean cortisol: immunoassay, $4.4 \mathrm{nmol} / \mathrm{L}$; IDLC-MS/MS $1.8 \mathrm{nmol} / \mathrm{L}$; concentration range: immunoassay, $1.5-12.6 \mathrm{nmol} / \mathrm{L} ; \quad$ ID-LC-MS/MS, 0.6-9.8 nmol/L; Figure 3).

\section{Discussion}

We have verified the applicability of the first automated immunoassay specified for the quantification of salivary cortisol in late-night saliva samples and report for a preliminary reference range from a population of apparently healthy adults. The upper limit of this range was $8.9 \mathrm{nmol} / \mathrm{L}$. In a two-centre imprecision study including two different reagent lots, a functional detection limit (CV $<20 \%$ ) of approximately $5.0 \mathrm{nmol} / \mathrm{L}$ was observed for the test. The reproducibility of the assay differed considerably between the two study laboratories (Table 2). This is despite the fact that optimal instrument and reagent handling procedures were performed by very experienced technicians in each centre and no evidence of technical malfunction was noted. This observation highlights that salivary cortisol measurement is technically very demanding owing to the extremely low target concentration ranges. Commercial availability of quality control materials in this low concentration range of salivary cortisol is highly desirable for routine clinical application of salivary analysis to detect any instrument malfunctions. Inclusion of salivary cortisol measurement in national and international proficiency testing schemes is also warranted.

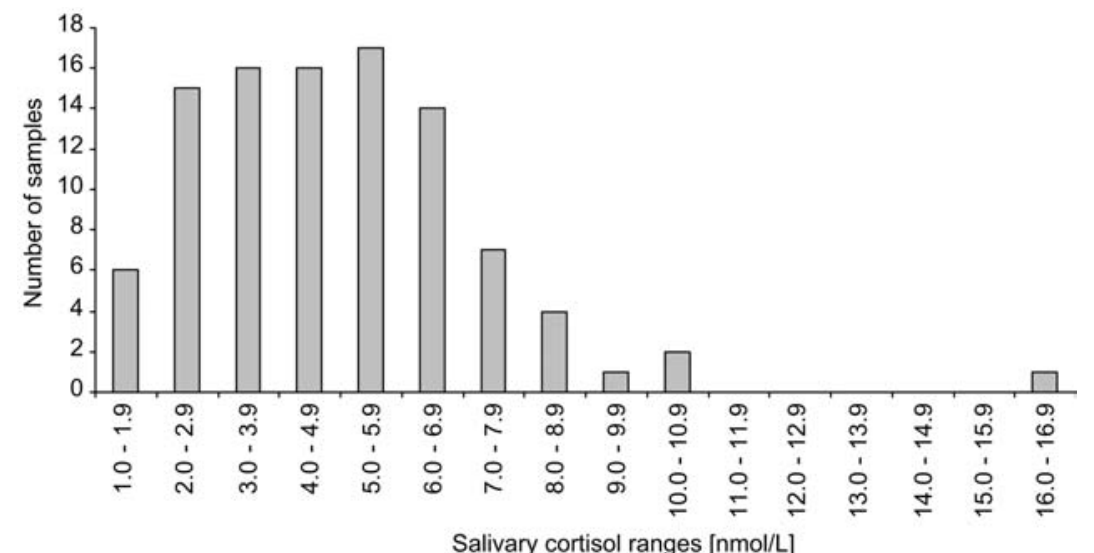

Figure 2 Distribution of 23:00-h salivary cortisol concentrations found in 100 apparently healthy adults using the Roche Cobas Cortisol assay. 


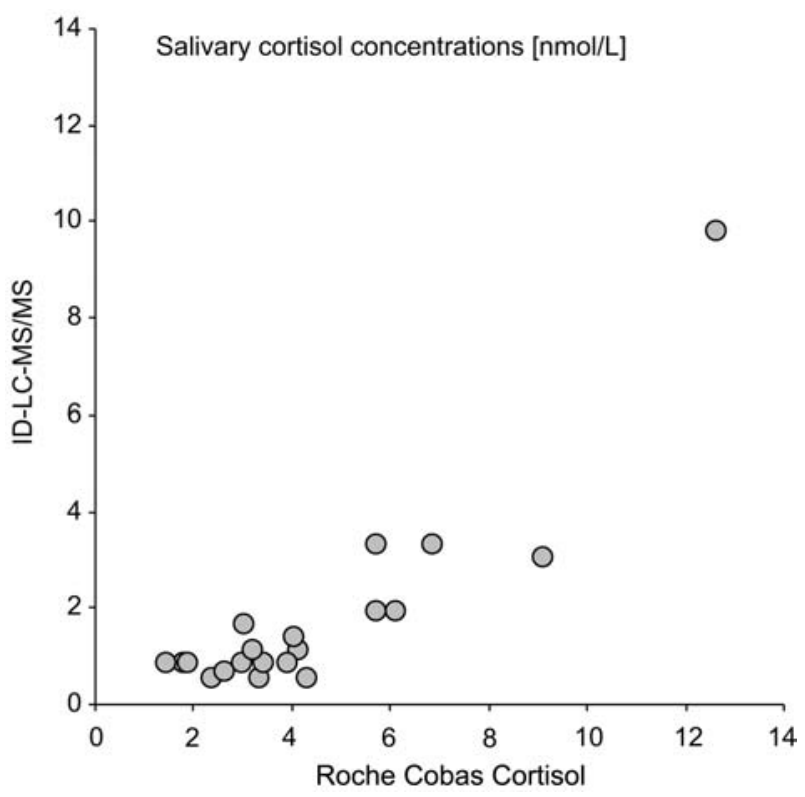

Figure 3 Method comparison of salivary cortisol results obtained with the Roche Cobas Cortisol assay and an isotope dilution liquid chromatography-tandem mass spectrometry method.

In a previous imprecision study of the Roche Cobas Cortisol assay for measurement of salivary cortisol (16), a clearly lower functional detection limit of $2.0 \mathrm{nmol} / \mathrm{L}$ was found; this discrepancy may be explained by the lower number of analytical series $(n=10)$ and the probable use of a single reagent lot in this previous investigation.

Since we observed poor agreement between salivary cortisol concentrations determined with the
Cobas cortisol assay and with isotope dilution ID-LCMS/MS, it must be emphasised that the reference range reported here for late-night salivary cortisol in a population of healthy volunteers is assay-specific. Poor agreement between immunoassay results and ID-LC-MS/MS has been described previously (17), with substantially higher concentrations found by a radioimmunoassay. These observations probably result from immunoassay cross-reactivities with endogenous steroids such as 6 $\beta$-hydroxycortisol and 21-deoxycortisol (16), but in particular with conjugated derivatives of cortisol. Different degrees of such analytical non-specificity - besides differences in the study populations - may explain the wide range of diagnostic cutoff values reported in previous investigations of salivary cortisol concentrations (3.6-15.2 $\mathrm{nmol} / \mathrm{L}$; Table 3). The mean late-night salivary cortisol concentration of $5.0 \mathrm{nmol} / \mathrm{L}$ found in our study in a healthy reference population, however, is in rather close agreement with the value of $3.6 \mathrm{nmol} / \mathrm{L}$ reported for the same cortisol assay in a previous study (16).

Since the matrix-independent ID-LC-MS/MS technology has the potential to harmonise salivary cortisol measurements in routine patient care, application of this technique to salivary cortisol measurement should be considered for the future, although the analysis is clearly far more demanding compared to immunometric cortisol quantification. Nevertheless, as summarised in Table 3, a number of studies on the diagnostic performance of late-night salivary cortisol measurements for diagnosing Cushing's syndrome by commercially available immunoassays have demonstrated a useful contribution of these methods. False-negative results, however, must be expected; these may in particular be due to cases of Cushing's

Table 3 Overview of studies on the diagnostic performance of late-night salivary cortisol measurement in diagnosing Cushing's syndrome (CS).

\begin{tabular}{|c|c|c|c|}
\hline Reference & Study population & $\begin{array}{l}\text { Analytical } \\
\text { method }\end{array}$ & Main results \\
\hline (8) & $\begin{array}{l}39 \text { patients with proven CS } \\
73 \text { normal subjects }\end{array}$ & $\begin{array}{l}\text { RIA } \\
\text { (DPC) }\end{array}$ & $\begin{array}{l}\text { Upper limit of the reference range }(23: 00 \mathrm{~h}) 3.6 \mathrm{nmol} / \mathrm{L} \text {; } \\
\text { mean salivary cortisol }(23: 00 \mathrm{~h}) \text { : normal subjects, } \\
1.2 \mathrm{nmol} / \mathrm{L} \text {, CS patients, } 24.0 \mathrm{nmol} / \mathrm{L} \text {; sensitivity } 92 \%\end{array}$ \\
\hline (9) & $\begin{array}{l}33 \text { patients with CS } \\
30 \text { normal volunteers } \\
18 \text { obese patients }\end{array}$ & $\begin{array}{l}\text { RIA } \\
\text { (in-house) }\end{array}$ & $\begin{array}{l}\text { Mean: normal, } 2.6 \mathrm{nmol} / \mathrm{L} \text {, obese, } 3.6 \mathrm{nmol} / \mathrm{L}, \mathrm{CS}, 25.1 \\
\mathrm{nmol} / \mathrm{L}(23: 00 \mathrm{~h}) \text {; range: subjects without CS } 1.7-10.8 \\
\mathrm{nmol} / \mathrm{L}, \mathrm{CS} \text { patients, } 5.0-59.6 \mathrm{nmol} / \mathrm{L} ; \\
\text { obese vs. CS: sensitivity } 93 \% \text {, specificity } 93 \%\end{array}$ \\
\hline (10) & $\begin{array}{l}122 \text { patients with CS } \\
34 \text { outpatients }\end{array}$ & $\begin{array}{l}\text { RIA } \\
\text { (Covance) }\end{array}$ & $\begin{array}{l}\text { Inpatient midnight or outpatient bedtime salivary cortisol } \\
>15.2 \mathrm{nmol} / \mathrm{L} \text { identified } 93 \% \text { of CS patients and excluded } \\
\text { all subjects without CS; mean bedtime }(21: 00-02: 00 \mathrm{~h} \text { ) sali- } \\
\text { vary cortisol in normal subjects } 7.2 \mathrm{nmol} / \mathrm{L} \text { (range } 5.8-15.2 \text { ) }\end{array}$ \\
\hline (11) & $\begin{array}{l}41 \text { patients with CS } \\
27 \text { healthy normal-weight } \\
\text { volunteers } \\
199 \text { individuals with simple obesity }\end{array}$ & $\begin{array}{l}\text { RIA } \\
\text { (Byk-Sangtec) }\end{array}$ & $\begin{array}{l}\text { ROC cutoff for midnight salivary cortisol } 9.7 \mathrm{nmol} / \mathrm{L} \text {; } \\
\text { sensitivity } 93 \% \text {, specificity } 93 \% \text { for } \mathrm{CS} \text { diagnosis; mean } \\
\text { midnight salivary cortisol in subject: normal, 5.0, obese, } \\
5.5, \mathrm{PC}, 6.3 \text {, and CS, } 26.8 \mathrm{nmol} / \mathrm{L}\end{array}$ \\
\hline (12) & $\begin{array}{l}63 \text { patients with CS } \\
54 \text { subjects with simple obesity } \\
\text { (mean BMI } 38.3 \mathrm{~kg} / \mathrm{m}^{2} \text { ) }\end{array}$ & $\begin{array}{l}\text { RIA } \\
\text { (CIS) }\end{array}$ & $\begin{array}{l}\text { Mean midnight salivary cortisol } 33.9 \mathrm{nmol} / \mathrm{L} \text { in CS patients } \\
\text { and } 2.2 \mathrm{nmol} / \mathrm{L} \text { in obese controls; proposed cutoff } \\
5.5 \mathrm{nmol} / \mathrm{L} \text { (sensitivity } 100 \% \text {, specificity } 96 \% \text { ) }\end{array}$ \\
\hline (13) & $\begin{array}{l}150 \text { patients with CS } \\
100 \text { healthy subjects }\end{array}$ & $\begin{array}{l}\text { RIA } \\
\text { (INCSTAR) }\end{array}$ & $\begin{array}{l}\text { Healthy subjects } 22: 00 \mathrm{~h} \text {, salivary concentration range } \\
<2.8-8.0 \mathrm{nmol} / \mathrm{L} \text {; proposed cutoff for diagnosis of CS } \\
4.4 \mathrm{nmol} / \mathrm{L} \text { (specificity } 100 \% \text {, sensitivity } 98 \% \text { ) }\end{array}$ \\
\hline (14) & $\begin{array}{l}12 \text { patients with CS } \\
20 \text { healthy volunteers } \\
16 \text { obese patients }\end{array}$ & $\begin{array}{l}\text { RIA } \\
\text { (CIS) }\end{array}$ & $\begin{array}{l}\text { Mean night-time salivary cortisol } 18.9 \mathrm{nmol} / \mathrm{L} \text { in } \mathrm{CS} \\
\text { patients, } 2.1 \mathrm{nmol} / \mathrm{L} \text { in healthy volunteers; proposed cutoff } \\
6.1 \mathrm{nmol} / \mathrm{L} \text { (sensitivity and specificity } 100 \% \text { ) }\end{array}$ \\
\hline
\end{tabular}


syndrome with inconsistent hormone secretion (18). Consequently, repeated sampling should be considered to increase diagnostic sensitivity (7). Falsely high salivary cortisol concentrations can result from sampling - which is normally unsupervised - earlier than the specified late-night hour.

In the present investigation including apparently healthy subjects, the performance of the Roche Cobas Cortisol assay for diagnosing Cushing's disease has not been investigated. However, the reference range established in the present study may serve as a preliminary cutoff in the diagnostic work-up of suspected Cushing's syndrome using the Roche cortisol assay. Definite cutoff concentrations for this assay should be assessed in future studies. During the study period, one case of histologically proven Cushing's disease was observed in centre 1; the late-night salivary cortisol was $11.6 \mathrm{nmol} / \mathrm{L}$ in this case, and was thus only slightly above the upper limit of the reference range identified in our investigation.

Salivary cortisol concentrations reflect unbound plasma cortisol concentrations and are therefore generally believed to be unaffected by variations in corticosteroid-binding globulin (CBG) concentrations (19). Indeed, we did not find statistically significant differences in late-night salivary cortisol concentrations for women taking hormonal contraceptive drugs compared to individuals not taking these drugs; women taking hormonal contraceptive drugs typically have high CBG concentrations (20). Furthermore, we did not observe a correlation between body mass index and late-night salivary cortisol. Besides the fact that salivary cortisol measurement seems to be largely unaffected by the important inter-individual variation of CBG, the non-invasive manner of sampling by the patient at home in a non-stressful surrounding argues in favour of this diagnostic approach. Shipment of samples to an outpatient clinic within $24 \mathrm{~h}$ after sampling seems acceptable, since good stability of cortisol in saliva has been reported (21).

\section{References}

1. Etxabe J, Vazquez JA. Morbidity and mortality in Cushing's disease: an epidemiological approach. Clin Endocrinol 1994;40:479-84.

2. Hammer GD, Blake-Tyrrell J, Lamborn KR, Applebury CB, Hannegan ET, Bell S, et al. Transsphenoidal microsurgery for Cushing's disease: initial outcome and long-term results. J Clin Endocrinol Metab 2004;89:6348-57.

3. Leibowitz G, Tsur A, Chayen SD, Salameh M, Raz I, Cerasi $E$, et al. Preclinical Cushing's syndrome: an unexpected frequent cause of poor glycaemic control in obese diabetic patients. Clin Endocrinol 1996;44:717-22.

4. Catargi B, Rigalleau V, Poussin A, Ronci-Chaix N, Bex V, Vergnot $V$, et al. Occult Cushing's syndrome in type-2 diabetes. J Clin Endocrinol Metab 2003;88:5808-13.

5. Arnaldi G, Angeli A, Atkinson AB, Bertagna X, Cavagnini $F$, Chrousos GP, et al. Diagnosis and complications of
Cushing's syndrome: a consensus statement. J Clin Endocrinol Metab 2003;88:5593-602.

6. Raff $\mathrm{H}$, Findling JA. A physiologic approach to diagnosis of the Cushing syndrome. Ann Intern Med 2003;138: 980-91.

7. Findling JW, Raff $\mathrm{H}$. Screening and diagnosis of Cushing's syndrome. Endocrinol Metab Clin North Am 2005;34:385-402.

8. Raff H, Raff JL, Findling JW. Late-night salivary cortisol as a screening test for Cushing's syndrome. J Clin Endocrinol Metab 1998;83:2681-6.

9. Castro M, Elias PC, Quidute AR, Halah FP, Moreira AC. Out-patient screening for Cushing's syndrome: the sensitivity of the combination of circadian rhythm and overnight dexamethasone suppression salivary cortisol tests. J Clin Endocrinol Metab 1999;84:878-82.

10. Papanicolaou DA, Mullen N, Kyrou I, Nieman LK. Nighttime salivary cortisol: a useful test for the diagnosis of Cushing's syndrome. J Clin Endocrinol Metab 2002;87: 4515-21.

11. Putignano $P$, Toja $P$, Bubini $A$, Giraldi FP, Coresllo SM, Cavagnini $F$. Midnight salivary cortisol versus urinary free and midnight serum cortisol as screening tests for Cushing's syndrome. J Clin Endocrinol Metab 2003;88: 4153-7.

12. Yaneva M, Mosier-Pudar H, Dugué MA, Grabar S, Fulla $Y$, Bertagna $X$. Midnight salivary cortisol for the initial diagnosis of Cushing's syndrome of various causes. J Clin Endocrinol Metab 2004;89:3345-51.

13. Trilck M, Flitsch J, Ludecke DK, Jung R, Petersenn S. Salivary cortisol measurement - a reliable method for the diagnosis of Cushing's syndrome. Exp Clin Endocrinol Diabetes 2005;113:225-30.

14. Viardot A, Huber P, Puder JJ, Zulewski H, Keller U, Müller B. Reproducibility of nighttime salivary cortisol and its use in the diagnosis of hypercortisolism compared with urinary free cortisol and overnight dexamthasone suppression test. J Clin Endocrinol Metab 2005;90: 5730-6.

15. Chiu SK, Collier CP, Clark AF, Wynn-Edwards KE. Salivary cortisol on Roche Elecsys immunoassay system: pilot biological variation studies. Clin Biochem 2003;36: 211-4.

16. van Aken MO, Romijn JA, Miltenburg JA, Lentjes EG. Automated measurement of salivary cortisol. Clin Chem 2003;49:1408-9.

17. Jonsson BA, Malmberg B, Amilon A, Helene Garde A, Orbaek P. Determination of cortisol in human saliva using liquid chromatography-electrospray tandem mass spectrometry. J Chromatogr B Analyt Technol Biomed Life Sci 2003;784:63-8.

18. Atkinson AB, Kennedy AL, Carson DJ, Hadden DR, Weaver JA, Sheridan B. Five cases of cyclical Cushing's syndrome. Br Med J Clin Res 1985;291:1453-7.

19. Hansen AM, Garde AH, Christensen JM, Eller NH, Netterstrom B. Evaluation of a radioimmunoassay and establishment of a reference interval for salivary cortisol in healthy subjects in Denmark. Scand J Clin Lab Invest 2003:64:303-10.

20. Wiegratz I, Kutschera E, Lee JH, Moore C, Mellinger U, Winkler UH, et al. Effect of four different oral contraceptives on various sex hormones and serum-binding globulins. Contraception 2003;67:25-32.

21. Gröschl M, Wagner R, Rauh M, Dörr HG. Stability of salivary steroids: the influences of storage, food and dental care. Steroids 2001;66:737-41.

Received April 28, 2006, accepted September 23, 2006 